\title{
A Study of Factors Affecting the Performance of Micro, Small, Medium- sized Enterprises in Indonesia
}

\author{
Andika Ayu Putri Ragil \\ Park Chung Hee School of Policy and Saemaul, 280 Daehak-ro, Gyeongsan Gyeongsangbukdo \\ 38541, Republic of Korea \\ Email: ragil.andikaayu@gmail.com
}

\section{ARTICLE INFO}

Date received : 03 January 2021

Revision date : 10 March 2021

Date received : 05 May 2021

\section{Keywords:}

MSMEs; firm's performance; entrepreneurial orientation; marketing information; funding

\begin{abstract}
This research aims to study the factors affecting MSMEs' performance in the Malang region and investigate the $0.5 \%$ final tax regulation role on MSMEs business in 2019. This study is quantitative research. The author conducted a survey shared to four hundred ninety-six MSMEs in Malang city and region and collected 217 questionnaires. Moreover, the author also collected tax and government regulation, previous research, books, and the internet. This study used Structural Equation Model (SEM) using AMOS 26. The result reveals that entrepreneurial orientation, funding, government policy, and the social and economic aspect affect the MSMEs' performance. The research shows that government policies are mediating funding in affecting the performance of MSMEs. It also explains explicitly that new tax regulation plays an essential role in enhancing the performance of MSMEs. However, marketing information and external institutions did not affect the performance of MSMEs in the Malang region.
\end{abstract}

\section{INTRODUCTION}

In this globalization era, micro, small, medium-sized enterprises are key actors in almost every production system (Jahanshahi et al., 2011), especially in emerging countries. They play a vital role by absorbing employees, contributing to Gross National Products, and reducing national disparity. Based on Indonesia National Statistic Bureau (2014), Indonesian business consists of less than $1 \%$ of big companies and $99.5 \%$ of MSMEs. The latter contributes to $60.34 \%$ of Indonesian Gross National Product and absorbs 114,144,082 employees, almost 50\% of the Indonesian population.

In 1997, MSMEs were the saviour of the Indonesian economic condition. During the infamous Asian Financial crisis, most financial and big companies collapsed; however, MSMEs could still run the business and become the Indonesian economic pillar.
Given the critical role of MSMEs, it becomes crucial for the government to protect the existence and the development of MSMEs. In order to develop, MSMEs should focus on their performance, both financial and non-financial performance. Enhancing their performance will boost other stakeholder trusts to consume their products and invest in their business. It later can strengthen the image of MSMEs, increase their profit and expand the business.

To escalate the performance of a business, MSMEs needs to consider both internal and external factors. Based on (Keh et al., 2007), internal factors can be entrepreneurial orientation and marketing. In his research, (Munizu, 2010) stated that funding could affect MSMEs performance. Meanwhile, external factors consist of government policy, social and economic

\begin{tabular}{ll}
\hline How to cite: & $\begin{array}{l}\text { Ragil, Andika Ayu Putri (2021) A Study of Factors Affecting the Performance of Micro, Small, } \\
\text { Medium-sized Enterprises in Indonesia, 2(3). https://doi.org/10.46799/jsss.v2i3.99 }\end{array}$ \\
\hline E-ISSN: & $2721-5202$ \\
\hline Published by: & Ridwan Institute \\
\hline
\end{tabular}


aspect, and external organization contribution (Munizu, 2010).

Businessmen are expected to have a three-dimensional orientation: risk-taking, proactive, and innovative (Keh et al., 2007). Besides, the former also needs to have 4P (product, price, promotion, place) marketingdecision, which is vital to create the product's value and attract a customer. Therefore, entrepreneurial orientation helps persuade them to pursue the goal and marketing skill. The latter connects EO to a firm's performance (Keh et al., 2007).

However, the different result showed by (Munizu, 2010) and (Linton \& Kask, 2017). They both stated in their research that Entrepreneurial Orientation directly affects MSMEs' performance. The result of discrepancies can be caused by the different political environment and government regulation for each country. Develop countries have more integrated information in term of policy and excellent business condition. While developing countries have still more lacks and less focusing on MSMEs' development.

The third internal factor, which also affecting MSMEs' performance, is funding. Unlike large companies that obtain funding from many resources, most MSMEs fund their business with private funding. However, using private funding is not entirely enough to operate a business. MSMEs needs more support from the external institution such as government, bank, and investor. In this case, most MSMEs could not fulfil external institutions' requirements for getting loans due to their lack of reporting skill.

Aside from the factors aforementioned, the external institution also has a role in MSMEs development. Government, as an example, may support MSMEs by providing policy and regulation. The Indonesian government launched many policies regarding financing for MSMEs, tax subsidy, and export easiness. Last 2018, the Indonesian government launched a new tax policy called Act No 23/2018. In this regulation, the government reduce the MSMEs tax rate to be $0.5 \%$ from $1 \%$. It aims to MSMEs, which has a gross revenue of fewer than 4.8 billion rupiahs. This regulation hopes to reduce MSMEs' burden to pay taxes.

Even though the government has already provided much support in regulation and training, MSMEs find that they still face a predicament situation to get legal certainty, sales permit, patent, and even funding. This situation stimulates other institutions contributing to the MSMEs development. Nowadays, it becomes a responsibility for a large company providing Corporate Social Responsibility to other stakeholders. One of the forms of CSR to stakeholders is providing training and financing. In Indonesia, PT Martha Tilaar and PT Astra are the two examples of big companies contributing to MSMEs enhancement. A Non-Governmental Organization is also trying to support MSMEs by providing training and workshop because it aligns with Sustainable Development Goals.

The last factor that can affect MSMEs performance is the social and economic situation. As developing countries, Indonesia has numbers of citizens living under $\$ 1$ every day, which scholarly referred to as under the poverty limit. Its situation also impacts the national consumption rate.

Based on the background mentionedabove, it can be seen the vital role of MSMEs in Indonesia. Therefore, this study would like to research factor affecting the performance of MSMEs in Indonesia. This research chooses the population in one of the big cities for MSMEs in Malang city and region.

\section{METHOD}

\section{Research Model}

This study conducted quantitative research and causal explanation. This study used four independent variables and two mediator variables. The independent variables are entrepreneurial orientation, government policy, social and economic aspect, and external institution support. Meanwhile, the mediator variables are financing and marketing information. Figure 1 explains the relationship between each variable.

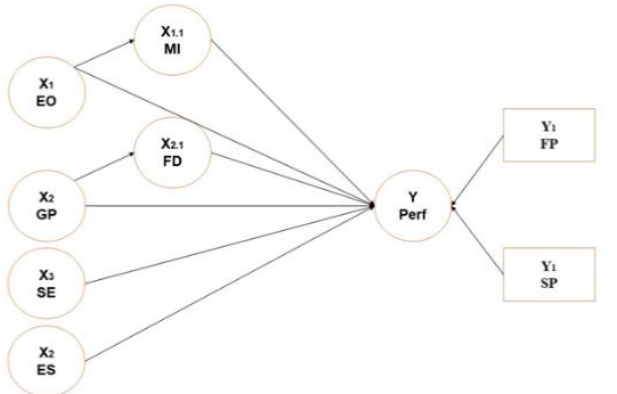

Picture 1 Research Model 
Note:

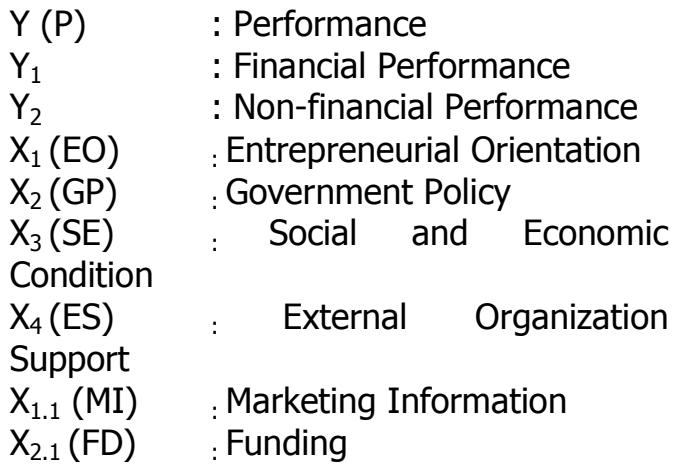

Based on some previous researches, Entrepreneurial Orientation (EO) plays an essential role in explaining a company's performance. Three dimensions of EO directly affect a company's performance in (Keh et al., 2007), (Munizu, 2010), (Santoso et al., 2015), and (Wiklund \& Shepherd, 2005) studies. However, in her research, Setyawati found that EO needs a mediator variable to impact its performance. The variable is the marketing mix (4P). Based on the reason aforementioned, this research constructs the hypotheses as below:

$\mathrm{H} 1$ : Entrepreneurial orientation affects the MSME's performance.

$\mathrm{H} 2$ : Entrepreneurial orientation positively affect the marketing mix.

H3: Marketing mix (MI) positively and directly affects MSMEs' performance.

Preparing fund is the most crucial part of operating a business. (Gathogo \& Ragui, 2014), (Munizu, 2010), and (Purwaningsih \& Kusuma, 2015) studies showed that capital or financing is the vital factor in increasing the performance and competitiveness of the firm. Meanwhile, the discrepancies result showed by Santos's study. In his research, (Santoso et al., 2015) explained that finance did not affect firms' performance significantly. The difference in financing variable may cause a difference in the result. Based on those explanations, this study constructs a hypothesis:

H4: Financing affects MSMEs' performance.

Even though financing provides a big help for operating a business, many MSMEs still find difficulties obtaining it, especially loan from external institution.
Thus, the Indonesian government launched many policies for financing the MSMEs. The government also created law tax regulation (UU No 23/2018) to decrease MSMEs' burden, increase access to financing, and escalate its performance. Both (Purwaningsih \& Kusuma, 2015) and (Munizu, 2010) claimed that there is a positive impact on MSMEs' performance caused by government policy. Thus, this study suggested that:

H5: Government policy positively affects MSMEs' financing.

H6: Government policy positively affects MSMEs' performance.

H7: Government tax's policy (UU No 23/2018) increases access to financing

If government policy through financing can affect the MSMEs performance, some research studies showed that external factors such as consumerism, income level, and businesses environment directly impact MSMEs performance (Purwaningsih \& Kusuma, 2015). Therefore, this study assumes that:

H8: Social and economic aspect positively affect MSMEs' performance. Another external factor that can influence MSMEs' performance is the external institution contribution. Currently, it becomes a responsibility for a large company to provide CSR to its stakeholders. It is also a shape of contribution for developing the nations. (Purwaningsih \& Kusuma, 2015) and (Munizu, 2010) researched this case and showed that a large company's assistantship could boost MSMEs' performance. Depart from the facts above; this study concludes that:

H9: External institution contribution positively affects MSMEs' performance.

2. Subject For The Study

This study uses Malang city and region MSMEs as a population. Using the data from Malang MSMEs' institution, there is 710 completed information on MSMEs. Therefore, this research distributed the questionnaire to each of MSMEs' owner or operational manager. The questionnaire shared using email, social media, and directly offline meeting.

3. Research Instrument 
This research distributed a questionnaire with a construction explained in Table 1. This study conducts reliability and validity test to determine the appropriateness of data. To examine the reliability, the researcher used SPSS 22 tools by seeing the point of alpha Cronbach. The instrument is reliable to use if the alpha Cronbach's point is more than 0.70 .

Meanwhile, to measure validity, this research used AMOS 22. There are two ways to determine the validity data, which are convergent and discriminant validity number. The threshold value of convergent validity is when the AVE is above 0.05 . The discriminant validity threshold is accepted when the value of the relationship between latent variables is under the square root AVE of each latent variable.

Table 1.

Measurement of Questionnaire

\begin{tabular}{|c|c|c|c|c|c|}
\hline & Variables & & Measurements & References & Question No \\
\hline \multicolumn{6}{|c|}{ Independent Variables } \\
\hline $\mathrm{x}_{1}$ & \multirow{3}{*}{$\begin{array}{l}1 \\
\text { Ontrepreneurial } \\
\text { Orientation }\end{array}$} & $\mathrm{x}_{1.1}$ & Innovativeness & \multirow{3}{*}{$\begin{array}{l}\text { Keh et. al (2007), } \\
\text { Purwaningsih \& Kusuma } \\
\text { (2015), Munizu (2010), } \\
\text { Setyawaty (2013), Wiklund \& } \\
\text { Shepherd (2005) }\end{array}$} & 1,2 \\
\hline & & $\mathrm{x} 1.2$ & Proactiveness & & 3,4 \\
\hline & & $\mathrm{x} 1.3$ & Risk Taking & & 5,6 \\
\hline \multirow[t]{3}{*}{$\mathrm{x}_{2}$} & \multirow[t]{3}{*}{ Government Policy } & $\mathrm{X}_{2.1}$ & Credit Policy & \multirow{3}{*}{$\begin{array}{l}\text { Purwaningsih \& Kusuma } \\
\text { (2015), Munizu (2010) }\end{array}$} & 1,4 \\
\hline & & $\mathrm{x} .2 .2$ & Tax Policy & & 2 \\
\hline & & $x_{2.3}$ & Regular Policy & & 3 \\
\hline \multirow{2}{*}{$\mathrm{x}_{3}$} & \multirow{2}{*}{$\begin{array}{l}\text { Social and } \\
\text { Economic Factor }\end{array}$} & $\mathrm{x}_{3.1}$ & Customer & \multirow{2}{*}{\begin{tabular}{|l} 
Purwaningsih \& Kusuma \\
(2015), Munizu (2010)
\end{tabular}} & 1 \\
\hline & & $x_{3.2}$ & Business Environment & & 2 \\
\hline \multirow[t]{2}{*}{$x_{4}$} & \multirow[t]{2}{*}{ External Support } & $\mathrm{x}_{4.1}$ & Government Assistance & \multirow{2}{*}{$\begin{array}{l}\text { Purwaningsih \& Kusuma } \\
\text { (2015), Munizu (2010) }\end{array}$} & $1,2,3,4,5$ \\
\hline & & $\mathrm{X}_{4.2}$ & MNC Assistance & & $1,2,4,5$ \\
\hline \multicolumn{6}{|c|}{ Mediating Variables } \\
\hline \multirow{4}{*}{$\mathrm{X}_{1.2}$} & \multirow{4}{*}{\begin{tabular}{|l} 
Marketing \\
Information
\end{tabular}} & $\mathrm{x}_{1.2 .1}$ & 1 Product & \multirow{4}{*}{$\begin{array}{l}\text { Keh et. al (2007), } \\
\text { Purwaningsih \& Kusuma } \\
\text { (2015), Munizu (2010), } \\
\text { Setyawaty (2013), Hadiyati } \\
\text { (2015) }\end{array}$} & 1 \\
\hline & & $x_{1.2 .2}$ & ${ }_{2}^{2}$ Promotion & & 2 \\
\hline & & $x_{1.2 .3}$ & \begin{tabular}{l|l}
3 & Distribution
\end{tabular} & & 3 \\
\hline & & $\mathrm{x}_{1.2 .4}$ & 4 Price & & 4 \\
\hline \multirow[t]{2}{*}{$x_{2.1}$} & \multirow[t]{2}{*}{ Funding } & $x_{2.1 .1}$ & 1 Owner's Capital & \multirow{2}{*}{\begin{tabular}{|l|} 
Gathogo \& Ragui (2014), \\
Purwaningsih \& Kusuma \\
(2015), Shin et. al (2017), \\
Munizu (2010), Santoso et. al. \\
(2014)
\end{tabular}} & 1,3 \\
\hline & & X.1.1.2 & 2 Credit & & $2,4,5,6$ \\
\hline \multicolumn{6}{|c|}{ Dependent Variables } \\
\hline \multirow[t]{2}{*}{$\mathrm{Y}_{1}$} & \begin{tabular}{|l} 
Financial \\
Performance
\end{tabular} & $\mathrm{Y}_{1.1}$ & Growth of Revenue & \multirow{2}{*}{$\begin{array}{l}\text { Keh et. al (2007), } \\
\text { Purraningsih \& Kusuma } \\
\text { (2015), Munizu (2010), } \\
\text { Setyawaty (2013), Gathogo \& } \\
\text { Ragui (2014), Santoso et. al. } \\
\text { (2015), Wiklund \& Shepherd } \\
\text { (2005) }\end{array}$} & $1,2,3$ \\
\hline & & $\mathrm{Y}_{1.2}$ & Growth of Profitability & & 4 \\
\hline
\end{tabular}

4. Data Collection Method

a. Questionnaire

This research distributed the questionnaire to 710 MSMEs existed in Malang city and region. They choose that number of MSMEs as the data has a complete address, mailing, and phone number.

b. Secondary data

Besides primary data, this research also collects secondary data such as the data from the Indonesia National Bureau.

5. Data Analysis

a. Structural Equation Model Assumption Goodness Fit Model

(Awang et al., 2015) stated that there are three model fit categories which explained in Table 2.

Table 2.

Alpha Cronbach's Reliability Level Alpha Cronbach's Reliability Level

\begin{tabular}{cc}
\hline $0.00-0.20$ & Less Reliable \\
\hline $0.21-0.40$ & Slightly Reliable \\
\hline $0.41-0.60$ & Fairly Reliable \\
\hline $0.61-0.80$ & Reliable \\
\hline $0.81-1.00$ & Very Reliable \\
\hline \multicolumn{2}{c}{ Source: Arikunto } \\
(2009:101)
\end{tabular}

Normality Test

A researcher conducts normality to know that the data has a normal distribution. The data is normal when the critical ratio is not more than 2.58 (Maglione et al., 2010).

\section{Outlier Test}

Outlier test examines the univariate and multivariate extremity. The data should not have an outlier problem and required $Z$ value between -1.96 and 1.96 , or the value of $p 1$ and p2 is more than 0.05 (Maglione et al., 2010).

Hypotheses Analysis

Constructed hypotheses will be accepted if the P-value less than 0.05 or the CR is more than 2.0.

\section{RESULTS AND DISCUSSION}

1. Research Result

a. Statistic Descriptive

After distributing almost 900 questionnaires to the whole MSMEs in Malang city and region online and offline, this research collected 208 questionnaires. Table 7 shows the proportion of MSMEs based on the questionnaire.

Table 3.

The Proportion of MSMEs' Respondent

\begin{tabular}{lcccc}
$\begin{array}{l}\text { Food and } \\
\text { Beverages }\end{array}$ & 88 & 70 & 14 & 4 \\
\hline Handicraft & 15 & 15 & 0 & 0 \\
\hline
\end{tabular}




\begin{tabular}{lcccc}
\hline Tourism & 3 & 3 & 0 & 0 \\
\hline Service & 4 & 4 & 0 & 0 \\
\hline Retail & 76 & 30 & 20 & 26 \\
\hline $\begin{array}{l}\text { Industry } \\
\text { Textile }\end{array}$ & 8 & 8 & 0 & 0 \\
\hline Others & 14 & 11 & 3 & 0 \\
\hline Total & 208 & 141 & 37 & 30 \\
\hline \multicolumn{5}{l}{ Source: Data Processed }
\end{tabular}

As table 3 shows, the majority respondent comes from food and beverages and retail sector. It becomes reasonable as Malang is famous as a tourism city. There are many tourist spots and amusement park which attract domestic tourist. At the weekend and long holiday, many families spend their time to go to Malang. Besides, Malang is also famous as an education city with many students from around Indonesia. The reason mentioned becomes an excellent opportunity for Malang's businessman to open a culinary business.

Table 4.

Respondent Personnel Information (Gender and Age)

\begin{tabular}{|c|c|c|c|c|c|c|}
\hline \multirow[t]{2}{*}{ Sector } & \multicolumn{2}{|c|}{ Gender } & \multicolumn{4}{|c|}{ Age } \\
\hline & $M$ & $\mathbf{F}$ & $\begin{array}{c}<20 \\
\text { years }\end{array}$ & $\begin{array}{c}20- \\
40 \\
\text { years }\end{array}$ & $\begin{array}{c}41- \\
60 \\
\text { years }\end{array}$ & $\begin{array}{l}>60 \\
\text { years }\end{array}$ \\
\hline $\begin{array}{l}\text { Food \& } \\
\text { Beverages }\end{array}$ & 24 & 64 & & 43 & 43 & 2 \\
\hline Handicraft & & 15 & & 5 & 10 & \\
\hline Tourism & & 3 & & & 3 & \\
\hline Service & 1 & 3 & & 4 & & \\
\hline Retail & 35 & 41 & 1 & 24 & 43 & 8 \\
\hline $\begin{array}{l}\text { Industry } \\
\text { textile }\end{array}$ & 1 & 7 & & 4 & 4 & \\
\hline Others & 4 & 10 & & 8 & 5 & 1 \\
\hline Total & 65 & 143 & 1 & 88 & 108 & 11 \\
\hline
\end{tabular}

The comparison of the gender for the respondent is $3: 8$. The female respondent is $68.75 \%$, and the male respondent is $31.25 \%$. Meanwhile, almost $95 \%$ of the respondent is in productive age, and $5 \%$ is the elderly. It is significantly showed that most businesses are family-owned that passed on to the next generation. Apart from the gender and age, the level of education of the respondent is also varied. Almost $46 \%$ of the respondent graduated from university, $37.5 \%$ graduated from Senior High School, and the rest graduated from Junior High and Elementary School (table 5).

Table 5.

Respondent Personnel Information (Education)

Source: Data Processed

\begin{tabular}{lcccc}
\hline \multirow{2}{*}{ Sector } & \multicolumn{4}{c}{ Education } \\
\cline { 2 - 5 } & ES & JHS & SHS & University \\
\hline $\begin{array}{l}\text { Food \& } \\
\text { Beverages }\end{array}$ & 5 & 10 & 30 & 43 \\
\hline Handicraft & & & 2 & 13 \\
\hline Tourism & & & 2 & 1 \\
\hline Service & & & 1 & 3 \\
\hline Retail & 8 & 13 & 34 & 21 \\
\hline Industry & & & 2 & 6 \\
textile & & & & \\
\hline Others & & & 7 & 7 \\
\hline Total & 13 & 23 & 78 & 94 \\
\hline
\end{tabular}

The respondent statistic showed that the businesses run for more than six years. Due to the high number of micro-sized entrepreneurship, many respondents have less than ten people, almost $87 \%$.

Table 6.

Company Information (Life of Business)

\begin{tabular}{lcccc} 
& Sector & \multicolumn{4}{c}{ Life of Businesses } \\
\cline { 2 - 5 } & $\begin{array}{c}<\mathbf{1} \\
\text { year }\end{array}$ & $\begin{array}{c}\mathbf{1}-\mathbf{3} \\
\text { years }\end{array}$ & $\begin{array}{c}\mathbf{3 - 6} \\
\text { years }\end{array}$ & $\begin{array}{c}\mathbf{> 6} \\
\text { years }\end{array}$ \\
$\begin{array}{l}\text { Food \& } \\
\text { Beverages }\end{array}$ & 9 & 29 & 14 & 36 \\
\hline Handicraft & 1 & 4 & 7 & 3 \\
\hline Tourism & & 2 & & 1 \\
\hline Service & 2 & 1 & & 1 \\
\hline Retail & 2 & 5 & 6 & 63 \\
\hline $\begin{array}{l}\text { Industry } \\
\text { textile }\end{array}$ & 1 & 3 & 4 \\
\hline Others & \multicolumn{5}{c}{3} & 1 & 10 \\
\hline Total & 14 & 45 & 31 & 118 \\
\hline \multicolumn{4}{c}{ Source: Data Processed }
\end{tabular}

Source: Data Processed 
Table 7.

Company Information (Number of Employees)

\begin{tabular}{|c|c|c|c|c|}
\hline \multirow[t]{2}{*}{ Sector } & \multicolumn{4}{|c|}{ Life of Businesses } \\
\hline & $\begin{array}{c}<1 \\
\text { yea } \\
r\end{array}$ & $\begin{array}{c}1-3 \\
\text { year } \\
s\end{array}$ & $\begin{array}{c}3-6 \\
\text { year } \\
s\end{array}$ & $\begin{array}{c}>6 \\
\text { year } \\
s\end{array}$ \\
\hline $\begin{array}{l}\text { Food \& } \\
\text { Beverages }\end{array}$ & 9 & 29 & 14 & 36 \\
\hline Handicraft & 1 & 4 & 7 & 3 \\
\hline Tourism & & 2 & & 1 \\
\hline Service & 2 & 1 & & 1 \\
\hline Retail & 2 & 5 & 6 & 63 \\
\hline Industry textile & & 1 & 3 & 4 \\
\hline Others & & 3 & 1 & 10 \\
\hline Total & 14 & 45 & 31 & 118 \\
\hline
\end{tabular}

Source: Data Processed

For the financing part, most of the samples use the owner funding and rarely use external finance sources. The high number of micro-sized entrepreneurship causes the decision for using the owner's funding. The former usually find it difficulties to get money from the external institution as they are the new entrepreneurship.

The result of descriptive statistic can be seen in table 8 . The result showed that marketing information, funding, and social and economic factor have a high level on the owner's perception with the value of 3.442, 3.526, and 3.976. However, the external service factor showed the lowest level of average on the owner's perception.

Table 8.

\begin{tabular}{|c|c|c|}
\hline \multicolumn{3}{|c|}{ Descriptive Statistic of Latent Variables } \\
\hline Variables & Mean & $\begin{array}{l}\text { Standard } \\
\text { Deviation }\end{array}$ \\
\hline Performance & 3.216 & 0.876 \\
\hline $\begin{array}{c}\text { Entrepreneurial } \\
\text { Orientation }\end{array}$ & 3.057 & 0.928 \\
\hline $\begin{array}{c}\text { Marketing } \\
\text { Information }\end{array}$ & 3.442 & 0.918 \\
\hline Funding & 3.526 & 0.851 \\
\hline Government & 3.394 & 0.812 \\
\hline Social and Economic & 3.976 & 0.848 \\
\hline External Service & 2.922 & 1.032 \\
\hline
\end{tabular}
Source: Data Processed

2. Validity and Reliability Test

$$
\text { According to Malang }
$$

MSMEs'institution, the number of MSMEs is 880 , consisting of 536 micro-sized, 272 small-sized, and 72 medium-sized enterprises. Despite the data collected from the MSMEs institution, there are 306 data with no complete profile. Hence, this study used 496 samples. The questionnaire distributed randomly to all 496 samples online and offline.

This research collected 217 questionnaires, but there are nine questionnaires that the respondent does not entirely fulfil. Thus, this research used 208 questionnaires as the total samples. The entities consist of 143 micro-sized, 33 small-sized, and 32 medium-sized enterprises.

Before analyzing the hypothesis, this research constructs a validity and reliability test. It aims to examine that the distributed questionnaires are appropriated to use as the research instruments.

The reliability test is measured using alpha Cronbach's measurement. As table 9, the result shows that the amount of alpha Cronbach's for each latent variable is above 0.70 . Thus, this data can be used for factor analysis.

Table 9.

Reliability Test Result (Cronbach's alpha)

\begin{tabular}{cccc}
\hline $\begin{array}{c}\text { Latent } \\
\text { Variables }\end{array}$ & $\begin{array}{c}\text { Numbe } \\
\text { r of } \\
\text { Items }\end{array}$ & $\begin{array}{c}\text { Droppe } \\
\text { d Items }\end{array}$ & $\begin{array}{c}\text { Cronbach' } \\
\text { s a }\end{array}$ \\
\hline Performance & 10 & - & 0.885 \\
\hline $\begin{array}{c}\text { Entrepreneuri } \\
\text { al Orientation }\end{array}$ & 6 & - & 0.880 \\
\hline $\begin{array}{c}\text { Marketing } \\
\text { Information }\end{array}$ & 4 & - & 0.890 \\
\hline Fund & 4 & - & 0.882 \\
\hline $\begin{array}{c}\text { Government } \\
\text { Policy }\end{array}$ & 4 & - & 0.881 \\
\hline $\begin{array}{c}\text { Social and } \\
\text { Economy } \\
\text { Condition }\end{array}$ & 2 & - & 0.884 \\
\hline $\begin{array}{c}\text { External } \\
\text { Support }\end{array}$ & 5 & - & 0.889 \\
\hline \multicolumn{2}{c}{ Sources: Data Processed } &
\end{tabular}

Meanwhile, for the validity test, the research uses two validity test methods; convergent and discriminant validity based on Structural Equation Model requirements.

a. Convergent Validity 
Convergent validity aims to test that each indicator validly measures the concept's dimension (Minto, 2016). The data is valid when the value of the Average Variance Extracted is above the recommended values of 0.5 .

The result for convergent validity shows that some latent variables measurement must be dropped due to their negative effect on AVE. Table 10 explains that there are eight measurements. The latter follows the recommendation from (Hair Jr et al., 2016), "any manifest variable standardized loading factor below 0.5 is required to be eliminated in order to improve AVE value of above 0.5."

Table 10.

Convergent Validity Test Result

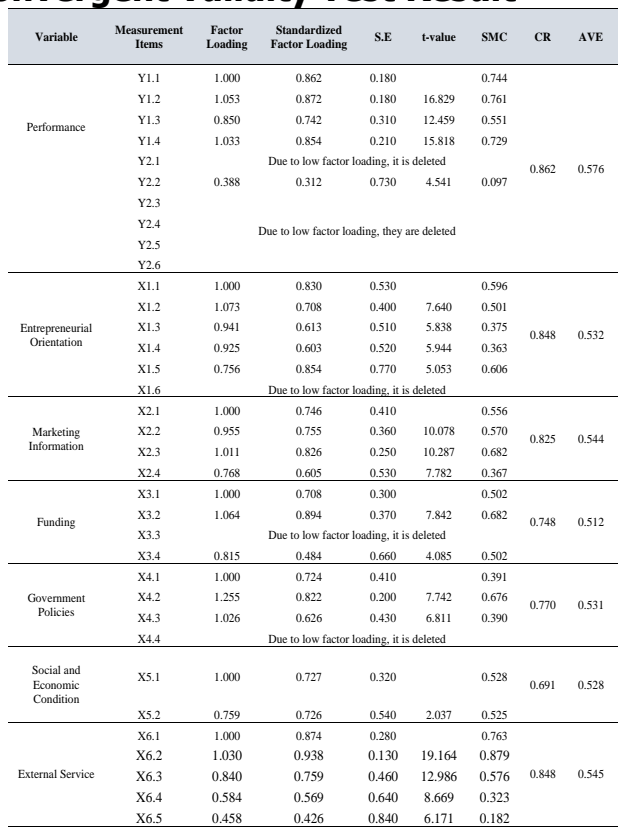

Source: Data Processed

b. Discriminant Validity

Discriminant validity aims to test whether two or more construct does not relate to each other. The measurement of discriminant validity is by comparing the average variance extracted with the squared correlation between constructs.
Table 11.

Discriminant Validity Test's Result

\begin{tabular}{lccccccc}
\hline \multicolumn{1}{c}{ Construct } & $\mathbf{1}$ & $\mathbf{2}$ & $\mathbf{3}$ & $\mathbf{4}$ & $\mathbf{5}$ & $\mathbf{6}$ & $\mathbf{7}$ \\
\hline Performance & 0.759 & & & & & & \\
Entrepreneurial & & & & & & & \\
Orientation & 0.310 & 0.729 & & & & & \\
Marketing Information & 0.125 & 0.000 & 0.737 & & & & \\
Funding & 0.277 & 0.000 & 0.000 & 0.715 & & & \\
Government & 0.235 & 0.000 & 0.681 & 0.000 & 0.728 & & \\
Social and Economic & 0.265 & 0.000 & 0.000 & 0.000 & 0.000 & 0.727 & \\
External Service & -0.095 & 0.000 & 0.000 & 0.000 & 0.000 & 0.000 & 0.738 \\
\hline
\end{tabular}

The test result shows that each of the latent variables constructs each other as the average variance extracted value is higher than 0.5 .

3. Normality and Outlier Test

After doing the validity test, the data should satisfy other requirements for the analysis factor, which the data should have a normal distribution and have no outlier problems. Thus, this study does normality and outlier test using AMOS 22 .

The output shows that the amount of critical ratio (CR) are less than 2.58 points. It concludes that the data have a normal distribution. Furthermore, it also shows no outlier problem as the result of p1 and p2 is higher than the threshold of 0.05 . Hence, the data of this research can be used for factor analysis AMOS 22.

Table 12.

Mahalanobis Distance

\begin{tabular}{cccc}
\hline $\begin{array}{c}\text { Observation } \\
\text { number }\end{array}$ & $\begin{array}{c}\text { Mahalanobi } \\
\text { s d-squared }\end{array}$ & p1 & p2 \\
\hline 71 & 32.582 & 0.211 & 0.075 \\
\hline 86 & 32.566 & 0.212 & 0.057 \\
\hline 58 & 31.363 & 0.256 & 0.362 \\
\hline 77 & 30.233 & 0.304 & 0.843 \\
\hline 196 & 29.975 & 0.315 & 0.887 \\
\hline 95 & 29.93 & 0.317 & 0.869 \\
\hline 185 & 29.905 & 0.318 & 0.842 \\
\hline 143 & 29.884 & 0.319 & 0.811 \\
\hline 133 & 29.832 & 0.322 & 0.789 \\
\hline 199 & 29.799 & 0.323 & 0.757 \\
\hline 148 & 29.72 & 0.327 & 0.745 \\
\hline 183 & 29.466 & 0.339 & 0.808 \\
\hline 101 & 29.256 & 0.349 & 0.846 \\
\hline 155 & 29.036 & 0.359 & 0.883 \\
\hline 127 & 28.444 & 0.388 & 0.972 \\
\hline 12 & 28.2 & 0.401 & 0.983 \\
\hline 163 & 28.2 & 0.401 & 0.976 \\
\hline 164 & 28.2 & 0.401 & 0.966 \\
\hline 187 & 28.169 & 0.402 & 0.958 \\
\hline 22 & 28.131 & 0.404 & 0.95 \\
\hline & & &
\end{tabular}




\begin{tabular}{|c|c|c|c|c|c|c|c|c|}
\hline 114 & 28.075 & 0.407 & 0.944 & \multirow{5}{*}{$\begin{array}{l}\text { All the measurement and data are } \\
\text { both in a marginal and good fit. It means } \\
\text { that the data is proper to use for factor } \\
\text { analysis. }\end{array}$} & \multirow{5}{*}{\multicolumn{4}{|c|}{$\begin{array}{l}\text { All the measurement and data are } \\
\text { in a marginal and good fit. It means } \\
\text { the data is proper to use for factor } \\
\text { sis. }\end{array}$}} \\
\hline 132 & 27.924 & 0.415 & 0.952 & & & & & \\
\hline 57 & 27.722 & 0.425 & 0.966 & & & & & \\
\hline 73 & 27.712 & 0.426 & 0.956 & & & & & \\
\hline 153 & 27.675 & 0.428 & 0.947 & & & & & \\
\hline 158 & 27.675 & 0.428 & 0.93 & \multirow{2}{*}{\multicolumn{5}{|c|}{$\begin{array}{l}\text { Table } 14 . \\
\text { Regression Weight Result }\end{array}$}} \\
\hline 103 & 27.661 & 0.429 & 0.912 & & & & & \\
\hline 9 & 27.632 & 0.43 & $0.896_{H}$ & potheses & Paths & C.R & t- & Results \\
\hline 109 & 27.509 & 0.437 & 0.904 & & & & value & \\
\hline 20 & 27.384 & 0.443 & 0.912 & \multirow[t]{2}{*}{ H1 (+) } & Entrepreneurial & 3.214 & 0.001 & Accepted \\
\hline 179 & 27.353 & 0.445 & 0.896 & & Performance & & & \\
\hline 104 & 27.024 & 0.462 & 0.948 & \multirow[t]{3}{*}{ H2 (+) } & Entrepreneurial & 2.706 & 0.007 & Accepted \\
\hline 169 & 26.929 & 0.468 & 0.949 & & $\begin{array}{l}\text { Orientation } \rightarrow \\
\text { Marketing }\end{array}$ & & & \\
\hline 159 & 26.761 & 0.477 & 0.961 & & Information & & & \\
\hline 200 & 26.547 & 0.488 & 0.975 & \multirow[t]{2}{*}{ H3 (+) } & Marketing & 1.595 & 0.111 & Not \\
\hline 174 & 26.387 & 0.497 & 0.981 & & Performance & & & \\
\hline 175 & 26.291 & 0.502 & 0.981 & \multirow[t]{2}{*}{ H4 (+) } & Funding $\rightarrow$ & 3.073 & 0.002 & Accepted \\
\hline 176 & 26.291 & 0.502 & 0.974 & & Performance & & & \\
\hline 107 & 26.193 & 0.508 & 0.975 & \multirow{2}{*}{ H5 (+) } & $\begin{array}{l}\text { Government } \\
\text { Policy } \rightarrow\end{array}$ & 5.255 & $0.000^{*}$ & Accepted \\
\hline 178 & 25.859 & 0.526 & 0.991 & & Funding & & & \\
\hline 129 & 25.849 & 0.527 & 0.987 & \multirow[t]{2}{*}{ H6 (+) } & $\begin{array}{l}\text { Government } \\
\text { Policy } \rightarrow\end{array}$ & 2.567 & 0.010 & Accepted \\
\hline 151 & 25.57 & 0.543 & 0.995 & & Performance & & & \\
\hline 102 & 25.056 & 0.571 & 0.999 & H7 (+) & $\begin{array}{l}\text { Tax Policy } \rightarrow \\
\text { Funding }\end{array}$ & 5.255 & $0.000 *$ & Accepted \\
\hline 81 & 24.728 & 0.59 & 1 & \multirow[t]{3}{*}{ H8 (+) } & Social and & 2.621 & 0.009 & Accepted \\
\hline 184 & 24.564 & 0.599 & 1 & & Economic $\rightarrow$ & & & \\
\hline 23 & 24.175 & 0.621 & 1 & & Performance & & & \\
\hline & 1OS 22 & essed & & H9 (-) & $\begin{array}{l}\text { External } \\
\text { Support } \rightarrow \\
\text { Performance }\end{array}$ & $1 . \overline{202}$ & 0.229 & $\begin{array}{c}\text { Not } \\
\text { Accepted }\end{array}$ \\
\hline
\end{tabular}

\section{Factor Analysis}

To do the AMOS analysis factor, a researcher needs to conduct a Structural Equation Model drawing (Picture 2). Before examining the factor, an SEM test should be done.

Structural Equation Model (SEM) examination is designed to check that the model is fit and proper to use. Measuring the model fit of SEM, this research used absolute, incremental, and parsimonious fit.

Table 13.

Result of Goodness Fit Model (part 2)

\begin{tabular}{|c|c|c|c|c|c|}
\hline \multirow[t]{2}{*}{ Type } & \multicolumn{5}{|c|}{ Incremental Fit } \\
\hline & AGFI & NFI & CFI & TLI & RMR \\
\hline $\begin{array}{l}\text { Literatur } \\
\text { e }\end{array}$ & $\begin{array}{c}\text { Tanaka } \\
\text { and } \\
\text { Huba } \\
\text { (1985) }\end{array}$ & $\begin{array}{l}\text { Bollen } \\
\text { (1989) }\end{array}$ & $\begin{array}{l}\text { Bentler } \\
(1990)\end{array}$ & $\begin{array}{l}\text { Bentler } \\
\text { and } \\
\text { Bonett } \\
(1980)\end{array}$ & - \\
\hline $\begin{array}{c}\text { Threshol } \\
\text { d }\end{array}$ & $\geq .90$ & $\geq .90$ & $\geq .90$ & $\geq .90$ & $\begin{array}{l}\leq \\
.05\end{array}$ \\
\hline & & & & & $\begin{array}{l}\leq \\
.10\end{array}$ \\
\hline Value & 0.702 & 0.686 & 0.769 & 0.744 & $\begin{array}{c}0.91 \\
9\end{array}$ \\
\hline Remark & $\begin{array}{c}\text { Margina } \\
\text { I Fit }\end{array}$ & $\begin{array}{c}\text { Margina } \\
\text { I Fit }\end{array}$ & $\begin{array}{c}\text { Margina } \\
\text { I Fit }\end{array}$ & $\begin{array}{c}\text { Margina } \\
\text { I Fit }\end{array}$ & $\begin{array}{c}\text { Good } \\
\text { Fit }\end{array}$ \\
\hline
\end{tabular}

Table 14 shows that seven hypotheses were accepted, while two hypotheses were rejected. The findings show that entrepreneurial orientation strongly affects MSMEs performance with the $t$-value (0.001), while government policy provides the lowest effect with the number of $t$-value 0.010 . Even though government policy provides the lowest effect, the former is facilitated well by funding to affect the performance. 


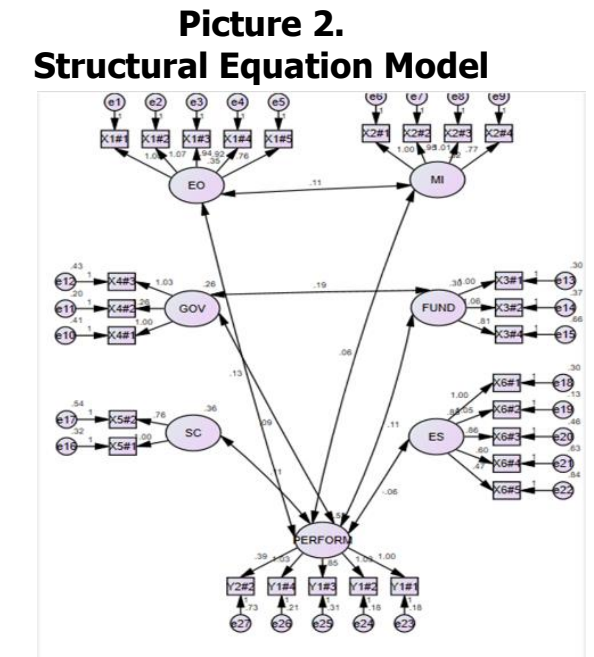

The result of this study explains that entrepreneurial orientation significantly affects the MSMEs' performance. The respondent education level may affect this result. Based on the statistic data (Table 15), almost $45.19 \%$ of the respondents have an upper-level diploma in their education. Some of the research said that the higher the knowledge, people would tend to be brave for taking a high-risk decision and be more tenacious. It then leads to affect the company's performance.

Table 15.

The Respondent Education (University Classification)

\begin{tabular}{cccc}
\hline No & $\begin{array}{c}\text { Level of } \\
\text { Education }\end{array}$ & Number & $\begin{array}{c}\text { \% of Total } \\
\text { Respondent }\end{array}$ \\
\hline 1 & Diploma & 72 & $34.62 \%$ \\
\hline 2 & Bachelor & 10 & $4.81 \%$ \\
\hline 3 & Master & 11 & $5.29 \%$ \\
\hline 4 & Doctoral & 1 & $0.48 \%$ \\
\hline & Total & 94 & $45.19 \%$ \\
\hline
\end{tabular}

Source: Data Processed

To start a business, people should do market research by collecting price, production, distribution, and promotion information. Human resource knowledge, such as innovativeness, pro-activeness, and risk-taking, plays an essential role in this stage.

The research result delivered the conclusion that entrepreneurial orientation positively affects marketing information. Like the entrepreneurial orientation effect on performance, the level of education is one aspect of this result. The respondent with a higher education level and are in a productive age tend to be more visionary as it can produce a high business performance.

Though entrepreneurial orientation is vital in every aspect of a business, some MSMEs do not improve their knowledge, leading them to be incapable of utilising market information. Later, it will cause a domino effect of the decreased performance or even bankruptcy.

In his book, (Thomas \& Renick, 1981) stated that "government policy is whatever the government chooses to do or not." To help a businessman operate their businesses, the government creates a policy that facilitates MSMEs in gaining finance, business legality, easier bureaucracy, protection from the foreign market, etc.

This research reveals that government policy significantly affects MSMEs performance with the value of $C R$ 2.567 and $t$-value 0.010 . It means that the government policy helps MSMEs to improve their performance.

This result can be attained as now, the Indonesian government also actively creating policy for MSMEs. These policies include Credit for UMKM to quickly getting financial support and taxation policy Act No $23 / 2018$ by decreasing the tax rate paid.

The explanation above also showed that government policy boosts MSMEs in gaining finance. The analysis also proves that the CR amount is 5.255 , and the tvalue is 0.000 . As mentioned before, the Indonesian government support the MSMEs industry to develop by providing Credit for MSMEs. It helps MSMEs to broaden their financing sources. MSMEs usually use internal sources from the owner's finance, but they have access to the external finance source using the Indonesian government policy. These processes later facilitate them diversifying their products and services, which can later promote more financial performance.

Apart from the three factors above, the business's social and economic condition affected MSMEs' performance. Most of the respondent explained that they could provide an affordable price of goods and product to the customer. It means that before producing, MSMEs 
already did market research to the business target. Besides, they already acknowledge their target, which mostly medium to low average income society.

Even though four factors already clarified the effect on the performance, marketing information and external institutions explained the opposite situation. Marketing information that should be the way for a businessman to promote their products does not affect financial and strategic performance. Indonesian MSMEs' structure is mostly micro-sized entrepreneurship, where they usually distribute and promote their products using "mouth to mouth" practice. Therefore, marketing information is not used by the respondent. In this research, marketing information may need mediator variables such as market orientation and competitive advantage to affect the performance.

The last factors not affecting MSMEs' performance is external institution support. As business face globalisation and free trade, small companies require more guidance from the government and large or even multinational companies to compete. The large companies and government have implemented many programs, but this research shows a contradictory result. With a $\mathrm{p}$-value of 0.229 and a t-value of 2 , the external institution does not affect the MSMEs' performance. Considering many MSMEs in Indonesia, it may happen because the government could not provide equal access to all the MSMEs. Most large companies also focus on MSMEs in big cities and less focus on small cities.

5. Discussion

The discussion of this result will be classified into two-points. The first will discuss the role of Act No 23/2018 on the MSMEs' development. The following discussion will cover the implication of all to the business environment.

a. Role of Act No 23/2018 on the MSMEs' Development

In the previous period, the government implemented Act No 46/2013 for MSMEs tax. This regulation stated that MSMEs with a total income per year of fewer than 4.8 billion rupiahs could choose to pay the flat
$1 \%$ tax rate or follow the progressive tax. This regulation aims to reduce MSMEs' burden that does not have bookkeeping reports and increase MSMEs' tax compliance. Nevertheless, the Act explains some complaints from Micro-sized entrepreneurship. The former is seen for not improving MSMEs performance and still gave a burden to the MSMEs. Using Act No 46/2013, some MSMEs still needs to pay taxes with a higher amount than if they use progressive tax regulation. Thus, the Indonesian government established Act No 23/2018 by reducing the tax rate by $0.5 \%$.

Some interviews with the respondent showed that Act No 23/2018 provides a slighter tax payment amount and reduces the MSMEs burdensome. Despite the payment of taxes could not directly affect MSMEs performance, it brings some preference for them. Firstly, the reducing of tax payment will increase their profit which the retained earning can be used for the next period of business operation. Second, it can increase MSMEs tax compliance, which leads to an increase in national income. It indirectly increases the Gross National Product.

Besides, following Act No 23/2018, MSMEs will gain more trust from the external institution or a third party such as a financial institution. They will have more choices to diversified their finance sources that they may need to expand and develop their business.

Despite developing the business, some MSMEs do not apply Act No $23 / 2018$ too. The condition happens due to the limited information and socialization from the government. Thus, this study suggests that the government enforce more deep socialization about the critical role of tax compliance for the business and country.

b. The Discussion and Implication

The prior study describes that information utilization shows an advanced level of entrepreneurial orientation. Businessman requires 
innovativeness, pro-activeness, and risk-taking to get the exact information on the market. According to (Keh et al., 2007), a profound thoughtful of customers such as purchasing habits, psychological makeup and lifestyle, entrepreneurial willingness, and entrepreneurial risk management can help a business owner conduct market segmentation and reduce risk during decision-making. Depart from this fact, it is enough to prove that entrepreneurial orientation is an essential part of business sustainability.

The findings showed that the higher the entrepreneurial orientation level, the more accurate customer utilization and market information. Nonetheless, the finding shows that marketing information does not affect MSMEs performance, although the former is still the mediator variable. As mentioned in the descriptive statistic, most respondents are micro-sized entrepreneurship with less than ten employees to run the business. As the smallest structure in the business, they may not be strong enough for being a price-maker. Thus, they usually take a role as price-taker in the market.

Other non-significant effects also show the relationship between product, distribution, and promotion on MSMEs performance.

1) As most MSMEs have limited funding for their business, almost all do not implement Research and Development to make a new product. They make minor changes in the physical form of products, such as appearance and size (Keh et al., 2007)

2) Most of MSMEs does not use a modern method to distribute their product.

3) As almost $50 \%$ of the respondents are in their old age, they do not become familiar with modern technology to promote their product. Therefore, MSMEs is unable to compete with the global market.

Although marketing information failed to show its contribution to the performance, (Setyawati, 2013) study revealed that market orientation significantly and positively affects the competitive advantage. Meanwhile, competitive advantage provides a direct and significant effect on performance (Potjanajaruwit, 2018). These findings contribute a significant implication the business. Sometimes, the fact said that information availability does not always head the company for gaining a better performance (Keh H.T. et al., 2007). A businessman should find a way to utilize the information to make their products or service outperform to be more interested.

Apart from entrepreneurial orientation and marketing information, financing as the internal factor also plays a critical role in MSMEs performance the more diverse the funding, the broader the opportunity to develop. The sources of finance are classified into two; internal and external. To gain external sources of finances, such as overdraft and longterm loan, a company should fulfil some requirements such as having a taxpayer registration number, business permit, financial statement and paying income tax.

This research found that government policy significantly affects financing. The implementation of the new tax policy reduces MSMEs' burden and helps to gain more external finance. Meanwhile, credit policy did not affect MSMEs performance because the former cause some burdensome to the creditor. As micro-sized entrepreneurship, they prefer to use the owner's capital rather than external finance. Moreover, with equity capital, the owner can control the business and enjoys profit whenever it is high and endures the risk alone (Adamu, 2019).

The findings provide implication both to the government and MSMEs. Considering the necessity of MSMEs, the government should create more on-target policy of getting external finance sources to MSMEs. Thus, the government can establish a softer loan accessible for MSMEs. On the other hand, a businessman should also enhance their ability to gain external 
finance sources by providing financial statement, innovative operation, and better market orientation.

Besides, a firm should also consider the social and economic condition of a business area. Doing a research market will help MSMEs decide on pricing and production. This research explains that social and economic condition affects positively MSMEs performance.

On the opposite, external support, both government and the multinational company, does not affect MSMEs performance. The Indonesian government has been done several ways to develop MSMEs, but the latter figured out many difficulties in distributing their products, getting property rights, and others. It is a predicament situation for MSMEs.

The identical result also showed the relation between MNC support on MSMEs. Many micro-sized entrepreneurship fails to attract multinational company interest. Furthermore, Multinational Company more focuses on the MSMEs located in big cities such as Jakarta and Bandung.

The result implies that MSMEs owner should focus on attracting and getting the trust of a multinational company and the government. The more innovative a company, the more attractable that is. Meanwhile, the government should also improve the method of improving MSMEs. Even though many opinions stated that it would be more profitable for the government to support large companies, we need to help MSMEs as the root of the country's economy to develop.

\section{CONCLUSION}

MSMEs plays a crucial role in the development of Indonesian economic development. They even became the saviour of the Indonesian economic when the country faced a chronic financial crisis in 1998. Nowadays, MSMEs face many global market challenges that demand them to be more innovative and competitive.

Various factor affects the performance of MSMEs both from external and internal. The findings show that entrepreneurial orientation, funding, government policy, and the social and economic condition affects MSMEs' performance. However, marketing information and external institution role did not affect.

Although this result showed significance, it also has some limitation, including to get data from the Ministry of MSMEs. This study collected 217 entities but could not compare the difference between each structure. Hence, this research suggests:

1. The next study can add more respondent with the proportional amount of each business structure to be more specific.

2. This study suggests the following research to add indirect effects such as technology and internet utilization.

3 . The next researcher may use other mediator variables such as competitive advantage and market orientation to know the direct and indirect effect of marketing information on MSMEs'performance.

\section{REFERENCES}

Adamu, A. (2019). Winners And Losers: Between Bank Loan And Small Medium Enterprises Equity Investment Scheme (SMEEIS) As Funding Sources For Northern Nigerian Smes. Faculty Of Commerce. Google Scholar

Awang, Z., Afthanorhan, A., \& Asri, M. A. M. (2015). Parametric And Non Parametric Approach In Structural Equation Modeling (SEM): The Application Of Bootstrapping. Modern Applied Science, 9(9), 58. Google Scholar

Gathogo, G. M., \& Ragui, M. (2014). Effects Of Capital And Technology On The Performance of Smes In The Manufacturing Sector In Kenya-Case Of Selected Firms In Thika Municipality. Google Scholar

Hair Jr, J. F., Sarstedt, M., Matthews, L. M., \& Ringle, C. M. (2016). Identifying And Treating Unobserved Heterogeneity With FIMIX-PLS: Part I-Method. 
European Business Review. Google Scholar

Jahanshahi, A. A., Nawaser, K., Sadeq Khaksar, S. M., \& Kamalian, A. R. (2011). The Relationship Between Government Policy And The Growth Of Entrepreneurship In The Micro, Small \& Medium Enterprises Of India. Journal Of Technology Management \& Innovation, 6(1), 66-76. Google Scholar

Keh, H. T., Nguyen, T. T. M., \& Ng, H. P. (2007). The Effects Of Entrepreneurial Orientation And Marketing Information On The Performance Of Smes. Journal Of Business Venturing, 22(4), 592-611. Google Scholar

Linton, G., \& Kask, J. (2017). Configurations Of Entrepreneurial Orientation And Competitive Strategy For High Performance. Journal of Business Research, 70, 168-176. Google Scholar

Minto, W. (2016). Mudah Cepat Tepat Penggunaan Tools Amos Dalam Aplikasi (SEM). UPN "Veteran" Jatim. Google Scholar

Munizu, M. (2010). The Influence Of External And Internal Factors On The Performance Of Micro And Small Enterprises (Mses) In South Sulawesi. Journal of Management And Entrepreneurship, 12(1), 33-41. Google Scholar

Potjanajaruwit, P. (2018). Competitive Advantage Effects On Firm
Performance: A Case Study Of Startups In Thailand. Journal Of International Studies, 11(3), 104-111. Google Scholar

Purwaningsih, R., \& Kusuma, P. D. (2015). Analisis Faktor-Faktor Yang Mempengaruhi Kinerja Usaha Kecil Dan Menengah (UKM) Dengan Metode Structural Equation Modeling (Studi Kasus UKM Berbasis Industri Kreatif Kota Semarang). Prosiding SNST Fakultas Teknik, 1(1). Google Scholar

Santoso, I., Yuwandini, D., \& Mustaniroh, S. A. (2015). Pengaruh Kredit Dan Sumber Daya Manusia Terhadap Kinerja UMKM Agroindustri Dengan Pemasaran Sebagai Variabel Antara. Jurnal Manajemen \& Agribisnis, 12(3), 174. Google Scholar

Setyawati, H. A. (2013). Pengaruh Orientasi Kewirausahaan Dan Orientasi Pasar Terhadap Kinerja Perusahaan Melalui Keunggulan Bersaing Dan Persepsi Ketidakpastian Lingkungan Sebagai Prediksi Variabel Moderasi (Survey Pada UMKM Perdagangan Di Kabupaten Kebumen). Fokus Bisnis: Media Pengkajian Manajemen Dan Akuntansi, 12(2). Google Scholar

Wiklund, J., \& Shepherd, D. (2005). Entrepreneurial Orientation And Small Business Performance: A Configurational Approach. Journal of Business Venturing, 20(1), 71-91. Google Scholar

\section{Copyright holder: \\ Andika Ayu Putri Ragil (2021)}

First publication right:

Journal of Social Science (JSS)

This article is licensed under: 